\title{
SUBJECT PANELS AS SUSTAINABLE INNOVATION FOR TEACHER PROFESSIONAL DEVELOPMENT
}

Godwin Mumhure

Morgenster Teachers College, Zimbabwe E-mail: mumhuregodwin@yahoo.com

Loyiso C. Jita

University of the Free State, Republic of South Africa

E-mail: jitalc@ufs.ac.za

Godsend T. Chimbi

University of the Free State, Republic of South Africa

E-mail: ChimbiGT@ufs.ac.za

\begin{abstract}
For centuries, teacher professional development has largely been done by external experts who advise teachers on how to improve classroom practice and learner performance. This research explores a relatively unchartered idea of history subject panels/clusters as an innovation meant to break away from orthodox teacher professional development spearheaded by external experts. The research adopts a qualitative case study design. One history subject panel was casestudied to examine how teachers initiated and sustained improvements in classroom practice and learner performance. Eight history teachers, who were active participants in the panel, were purposively sampled out of 25 teachers who constituted the history subject panel. Data were gathered through semi-structured interviews, document analysis and focus group discussion. Symbolic interactionism was used as the theoretical lens to gain deeper insights into how teachers socialised and shared ideas in the subject panel. Results indicated that the history subject panel was involved in the induction of new history teachers into the profession and the creation of learning communities for history students; practices hitherto undocumented in existing literature on subject panels and teacher networks. Results also showed that the activities of the history subject panel improved teachers' classroom practice. The implications of this research are that teacherled subject panels need to be nurtured and supported so that teacher-driven continuous professional development can be enacted across all the subjects offered in the school curriculum. Subject panels can reduce schools' dependency on external experts for teacher professional development, making teachers the proverbial doctors who can heal themselves.
\end{abstract}

Keywords: history subject panels/clusters, qualitative case study, teacher induction, student learning communities, sustainable innovation, teacher professional development

\section{Introduction}

The creation of subject panels is a shift from the traditional top-down teacher professional development models that are spearheaded by external experts hired from outside the school system. Subject panels place teacher improvement squarely in the hands of the teachers who need a remedy to improve their practice and, ultimately, learner performance. But, globally, 
Godwin MUMHURE, Loyiso C. JITA, Godsend T. CHIMBI. Subject panels as sustainable innovation for teacher professional development

PROBLEMS

OF EDUCATION IN THE $21^{\text {st }}$ CENTURY Vol. 78, No. 5, 2020

800

teacher professional development has mainly been practiced as a top-down initiative wherein teachers often play a subordinate role as they are told what to do to improve their classroom practices (Chikoko, 2007; Dehghan, 2020; Govender, 2018; Hardman et al., 2015). Subject panels, also known as subject clusters or teacher networks, are a relatively new phenomenon in teacher professional development, especially in the developing world (Jita \& Mokhele, 2012; Shikalepo, 2018). As a result, from their inception, the purpose and activities of subject clusters have been a bone of contention between teacher leaders (who often run them) and the school administrators (who supervise them and the teachers) (Chikoko \& Aipinge, 2009).

The establishment of subject panels, thus, seems to have created two centres of power in the school system, threatening the dominant hierarchical unipolar power structure which revolves around the school principal. Most heads of schools are used to traditional teacher development practices which emanate from "upper sources of authority" (Dehghan, 2020, p. 3); such as curriculum supervisory authorities or policymakers. Despite efforts to decentralise school leadership, conventional staff development programmes tend to follow a bureaucratic hierarchy of power which is still functional in most schools.

The subject-cluster model breaks away from the orthodox top-down paradigm by adopting a bottom-up, teacher-centric approach to teacher professional development (Dehghan, 2020; García-Martínez \& Tadeu, 2018; Tikkanen et al., 2019). In this context, the initiative to improve teacher professional practice is placed in the teacher's hands, rather than administrators and/ or external experts - more akin to a doctor who prepares remedies for him- or herself. Recent research has shown that classroom practice improves when teachers are given the autonomy to find solutions to challenges they encounter in their practice (Gore \& Rosser, 2020; Govender, 2018; Mansfield \& Thompson, 2016; Rincon-Gallardo \& Fullan, 2016; Stacy, 2013). When teachers are involved in their own professional development, their confidence with, ownership of and commitment to new ideas and school reform increase.

\section{Models for Teacher Professional Development}

Several models have been developed to support teacher professional development in many countries and in different contexts (Mokhele, 2011). But traditional teacher professional development has largely been characterised by sporadic once-off workshops intended to provide teachers with the latest information on particular aspects of their work (Bett, 2016). Traditional teacher development is usually unconnected to teachers' classroom realities because it is often led by hired external experts (Dehghan, 2020). This commonly used approach is often called staff development in many countries.

\section{Staff Development Model}

The staff development model is the traditional top-down approach often initiated by curriculum supervisory authorities, university experts and/or school administrators who spearhead teacher professional development (Ngcoza \& Southwood, 2015; Ngema \& Lekhetho, 2019; Tikkanen et al., 2019). Traditional staff development workshops are led by external experts, hired from outside the school, and teachers are semi-passive recipients of the new knowledge that is expected to improve their practice. This model has been tried and tested in both developed and developing countries, with varying degrees of success.

Villegas-Reimers (2003) found that staff development workshops improved learners' achievement in mathematics and writing skills in Australia when teachers shared their pedagogical challenges with the external experts who came to assist them. However, many studies (Ngema \& Lekhetho, 2019, Wong \& Bautista, 2017; Yates, 2012) have found this authority-oriented approach to teacher professional development to be ineffective in promoting 
sustainable school reform and changes in classroom pedagogy. This is mainly because hired Vol. 78 , No. 5, 2020 experts are far removed from classroom realities and the unique contexts particular schools and teachers operate in. So, the past decades have seen a paradigm shift in the way teacher professional development is conceptualised. Current research (Dehghan, 2020; GarcíaMartínez \& Tadeu, 2018; Govender, 2018; Tikkanen et al., 2019) is advocating for schoolbased professional development models that are organised and led by the teachers themselves.

\section{School Clusters}

The new perspective suggests that teacher professional development should be led by the teachers themselves and be closely aligned to their daily work (García-Martínez \& Tadeu, 2018; Tikkanen et al., 2019). Thus, teacher professional development is now regarded as a collaborative process in which teachers learn from each other and initiate or adapt professional development programmes to suit their unique contexts and specific needs (Ajani, 2019; Picower, 2015). School clusters, also known as school networks, aim at bringing together schools in one geographical area and pool resources and expertise to support school reform and teacher professional development.

The Australian National School Network (NSN), for instance, was used to identify challenges preventing schools from implementing new ideas to improve teaching and learning (Day \& Sachs, 2004). This project has been credited for successful pedagogical reform in over 400 Australian schools. It linked teacher professional development to ongoing school-based research, transformed classroom practice and improved teacher competency and, ultimately, learner performance. School clusters have also been popular as a model for improving school administration, reform implementation and teacher competency in Nigeria (Ajani \& Govender, 2018); Tanzania (Hardman et al., 2015); South Africa (Jita \& Mokhele, 2012) and Namibia (Shikalepo, 2018). In Zimbabwe, school clusters were introduced as a joint initiative by the governments of Zimbabwe and the Netherlands to promote quality education under the Better Schools Programme in 1993 (Chikoko, 2007). Subject clusters were later introduced in 1999 as sub-units of the school clusters.

\section{Teacher Networks}

Teacher networks, also known as professional learning communities, subject clusters or subject panels, even though the terms have their own nuances, are a relatively new model for teacher professional development in most developing countries (García-Martínez \& Tadeu, 2018; Nakambonde-Daniel, 2018); although there is a rather long history of subject panels in the developed countries. This model brings together teachers from the same or different schools to address the common problems they encounter in their practice. For instance, secondary school teachers who teach the same subject can form a subject panel which promotes their collective interests. Teacher networks can also play a mentoring role in which experienced teachers assist novice teachers on how they can improve pedagogical practice and become better and more effective teachers (Falyakhov, 2018; García-Martínez \& Tadeu, 2018).

Wong and Bautista (2017) argued that teachers should be responsible for managing the subject networks to wean off dependency on external experts. However, some studies have recorded power struggles between school principals and teacher leaders for the control of subject clusters (Chikoko \& Aipinge, 2009; Jita \& Mokhele, 2012). Not much research has been done to explore the activities of subject panels, especially in Zimbabwe as previous studies tended to focus more on school clusters as opposed to subject panels (Chikoko, 2007; Delport \& Makaye, 2009; Maphosa et al., 2013). The current research sought to gain insights into the workings of one history subject panel at the grassroots level. 
Godwin MUMHURE, Loyiso C. JITA, Godsend T. CHIMBI. Subject panels as sustainable innovation for teacher professional development

PROBLEMS

OF EDUCATION

IN THE $21^{\text {st }}$ CENTURY Vol. 78, No. 5, 2020

802

\section{Functions of Teacher Networks}

The literature suggests that teacher networks engage in a variety of activities designed to improve teaching and learning in schools. In the Russian Federation for instance, Falyakhov (2018) established that teacher clusters help to bring together experienced mentors with new college graduates so that they can learn from one another. Falyakhov (2018) emphasised that, "not only those who have a lot of experience in pedagogical work, but also those who have just come out of the trainees' environment may and should be mentors, because production needs new generators of ideas, which, as we know, should be sought among young people, and they, in turn, need experience to consolidate the acquired knowledge ..." (p. 93). Clusters make learning an iterative and collaborative process between the experienced mentors (with their tried and tested practices) and the inexperienced (with their new and untested knowledge), which may prove useful in initiating and fostering pedagogical change.

In their study of cluster-based professional development in New Zealand, Starkey et al. (2007) found that secondary school teachers participated in various job-embedded activities and the implementation of standards-based assessment as required by the New Zealand education authorities. In Zimbabwe, South Africa and Namibia teacher clusters also spend most of their time advancing the policy agendas of their governments (Chikoko \& Aipinge, 2009, Maphahlele \& Rampa, 2015; Nakambonde-Daniel, 2018).

In Zimbabwe and Namibia, clusters provide opportunities for teachers to work together on syllabus interpretation, scheming and setting common test papers and marking guides (Maphosa et al., 2013; Shikalepo, 2018). Owens, Pogodzinsk and Hill (2016) observed that, "professional development is most effective when it is relevant to the teachers by being intensive, ongoing and connected to practice" (p. 207). In Nigeria, Nwagbara (2014) found that teachers discuss difficult concepts, teaching-learning techniques, develop instructional media and jointly plan lessons in their clusters.

\section{Challenges Faced by Teacher Networks}

Teacher networks require proper management if they are to fulfil their teacher professional development mandate. Wong and Bautista (2017) argued that teacher networks must be managed by the teachers themselves, leaving most clusters with practical organisational challenges. In Zimbabwe, teacher clusters were introduced as sub-units within school clusters, making them unpopular with school principals, who felt that teacher leaders were somehow usurping their powers (Chikoko, 2007). Some teacher clusters are made up of teachers working in schools that may be far apart. Problems of distance and teacher absenteeism at professional development sessions have been found to be rampant (Kennedy, 2011). Battersby and Verdi (2015) found that small schools often struggle to fund teachers to attend professional development seminars conducted at distant stations. As a result, teachers end up not attending the teacher networks, making them miss out on new ideas and interactions, which could have helped them improve their classroom practice and support school reform efforts.

\section{Theoretical Framework}

The theory of symbolic interactionism provided guidance for this research on teacher activities, collaboration and collegiality during history subject panel meetings and seminars. The theory, as articulated by George Herbert Mead and Herbert Blumer, holds that human beings construct meaning of the world through interaction, communication and working together in social and professional groups (Haralambos et al., 2013). This research focused on the meanings the high school history teachers ascribed to the history subject panel as they 
engaged in discussions and shared ideas on history pedagogy and classroom management. They dialogued on effective instructional practice, how they could improve their own teaching and student performance.

The research sought to understand, from the teachers' perspective, how facilitators for the history subject panel seminars were selected, who set the agendas for the meetings, and the type of activities they engaged in during the panel meetings/seminars. Through interaction, active and collaborative learning, the teachers engaged with content and pedagogical knowledge of history as an academic subject. Academic and social interaction in the panel enabled the teachers to suggest possible solutions to the challenges they encountered in their practice, making symbolic interactionism an appropriate theoretical lens for this research. The current research sought to explore whether (and how) the activities of the selected history subject panel were empowering teachers to professionally develop themselves without input form external experts.

\section{Research Aim and Research Questions}

This research aimed at exploring how teachers in a history subject cluster challenged the implicit notion that they may not be well placed to provide sustainable solutions to problems of practice by initiating and sustaining their own professional development. The central argument is that subject panels can provide sustainable, teacher-led, grassroots innovations for teacher professional development, which has, hitherto, been in the hands of external experts. Two major questions driving the argument in this research were:

- What were the unique practices of a history subject panel that served as a platform for school-based teacher professional development?

- How can these practices be supported and/or sustained?

\section{Research Methodology}

\section{General Background}

A qualitative research approach was adopted to examine the innovations of one subject panel in the Masvingo District of Zimbabwe. The adoption of the qualitative research approach was partly informed by the theory of symbolic interactionism (Haralambos et al., 2013), which was used as a lens to understand how participants constructed meanings through interaction. Cohen, Manion and Morrison (2011) argued that the social world can only be understood from the "standpoint of the individuals who are part of the ongoing action being investigated" (p. 15). The qualitative research approach was also deemed appropriate to gather rich descriptive data from informed participants (Creswell, 2013), on the activities of the selected history subject panel. Permission to collect data for this research was granted by the University of the Free State Education Ethics Board in June 2015 under Ethics Clearance Number UFSHS2015/0291; which was subsequently used to apply for access to schools and history subject panels in Zimbabwe from the Ministry of Primary and Secondary Education.

\section{Research Design}

A case study research design was adopted to gain deeper insights into the activities of one history subject panel. The panel was case studied from July 2015 to March 2016. Although the case study research design has often been criticised for its limited generalisability to a wider population, its particularisation can also be seen as its main strength because, "it can provide insights that may be useful in other related contexts" (Spillane, 2000, p. 309). The case study 
Godwin MUMHURE, Loyiso C. JITA, Godsend T. CHIMBI. Subject panels as sustainable innovation for teacher professional development

PROBLEMS

OF EDUCATION IN THE $21^{\text {st }}$ CENTURY Vol. 78, No. 5, 2020

804

design allowed for prolonged engagement with the panel to observe how it operated and the challenges it encountered as a novel approach to teacher professional development. Secondary school teachers who participated in history subject panels in Masvingo Province were targeted. For logistical and financial reasons, the whole target population could not be involved in the research (Cohen et al., 2011), making sampling inevitable.

\section{Sample Selection}

Purposive sampling was used to select the most active panel. The most active panel was a history cluster which held two or three meetings/seminars per school term (the school calendar has three terms a year); and had documented minutes of such activities. The most active panel for the purposes of this research was found to be the Masvingo District history subject cluster. Eight history teachers were purposively sampled; one from each of the eight schools that made up the Masvingo District history subject panel. The panel had a total of 25 history teachers. The selected participants were Advanced Level (A-level/Form 5 \& 6) history teachers. In Zimbabwe A-level are the preparatory classes for university studies. These teachers were either members of the panel executive committee, experienced facilitators, or just active members (most involved in activities) of the panel. Potential participants were asked if they were willing to take part in the research. Those who agreed signed consent forms as proof of voluntary participation. They were informed of their right to withdraw from the research with or without giving any reasons and were assured of confidentiality through the use of pseudonyms.

\section{Instruments and Procedures}

Document analysis, semi-structured interviews, observations and a focus-group discussion (FGD) were used to gather data. Document analysis involved an examination of the minutes of the meetings and seminars the panel held. The minutes provided vital information on the venues for the panel meetings/seminars, agendas, facilitators, attendance and the activities the panel engaged in. Information from the minutes helped in focusing the questions in the interview guide, FGD protocol and the observation schedule. Semi-structured interview questions were used to solicit views and opinions on the efficacy of the history subject panel from the eight teachers sampled. The interviews focused on how facilitators were selected, the setting of the agendas, the activities of the panel, the challenges teachers faced, the viability of the panel, and how the panel could be improved. Interviews were tape recorded and later transcribed verbatim into typed text using a word processor.

The first researcher attended and observed four history subject panel meetings between July 2015 and March 2016 as a non-participant observer. He did not participate in the meetings but asked for permission (from the panel executive committee) to sit-in, audio-record and take notes on the proceedings. Three meetings were workshops for history teachers. The teacherfacilitators engaged their colleagues in discussion and debate on how they could assist students interpret the key words used in essay questions and improve their essay writing skills. One meeting was a seminar in which A-level history students presented papers they had researched from past examination questions. The seminar strengthened learning communities for history students and prepared them for their final external examinations. The observation guide used by the first researcher identified the facilitators, the nature and quality of interactions, the locus of power and control, comments the teachers made and how differences were resolved. These observations were meant to authenticate the responses participants gave in the interviews. They also provided first-hand information on the activities of the history subject panel as a platform for teacher professional development. 
One focus group interview brought together all the eight participants for an FGD. The IN THE $21{ }^{\text {st }}$ CENTURY aim was to allow the eight history teachers to engage in a collective discussion on how the history panel was functioning and promoting (or failing to promote) the interests of the history teachers. The FGD had a duration of one and a half hours and was audio-recorded for latter transcription into typed text. The discussion verified the authenticity of the responses given in the interviews by the participants. Rabiee (2004) advised that the focus group interview generates data which "are often deeper and richer than those obtained from one-to-one interviews... as well as illuminating the differences in perspective between groups of individuals" (p. 656). The FGD raised some issues which the researchers had not captured in the focus group interview guide, like school principals' negative attitudes towards the history panel and overcrowding at the panel seminars. It also generated unrestricted conversation and debate on the activities, successes and challenges of the history subject panel as a grassroots innovation to teacher professional development.

\section{Data Analysis}

Data gathered from minutes of the subject panel meetings/seminars, observations, audiorecorded one-on-one interviews and the focus group interview were electronically transcribed using a Microsoft-Word processor. The transcribed and printed data were then manually coded, categorised, tabulated and arranged to decipher convergencies, divergences as well as emerging themes. Documentary data from the minutes of the subject cluster meetings and seminars were examined through interpretive content analysis to make sense of what was written (Bogdan $\&$ Biklen, 1992). The written evidence was then coded and categorised into themes to show the agendas of the meetings, the facilitators and the activities the panel engaged in. Data from transcribed one-on-one interviews and observation protocols were examined, coded, categorised and reduced to bring out common ideas. The common ideas from the interviews and observations were then synthesised, aggregated and crystallised into emerging themes.

Analysis of data from the FGD went through several stages starting with examining the 32-page volume of the transcribed group interview text. This first stage of analysis involved making sense of the data and "getting rid of extra and irrelevant information" (Rabiee, 2004, p. 657), which participants had brought up during the discussion. The evidence from the group discussion, which was deemed relevant to the research questions, was then categorised, coded, tabulated and reduced into manageable units. Data from the FGD was triangulated with data from the interviews, documents and observations to check for uniqueness, similarities, consistency and authenticity. Evidence from the four research tools was then aggregated and crystallised into emerging themes which are presented in the next chapter.

\section{Research Results}

This research explored and unpacked the activities and efficacy of the Masvingo District history subject panel as a teacher-managed innovation for teacher professional development in Zimbabwe. Four themes emerged during data analysis: selection of facilitators, agendas for panel meetings, activities during panel meetings and efficacy of the subject panel.

\section{Selection of Facilitators}

The research sought to determine from participants how facilitators were selected to lead discussions in the history subject panel. Mberi, a member of the panel executive committee, explained that: "Usually we select somebody with marking experience [of external examinations] or somebody who has been in the field for some time." He also suggested that 
Godwin MUMHURE, Loyiso C. JITA, Godsend T. CHIMBI. Subject panels as sustainable innovation for teacher professional development

PROBLEMS

OF EDUCATION IN THE $21^{\text {st }}$ CENTURY Vol. 78, No. 5, 2020

806

the subject panel did not often use external experts because "they are out of touch with what is happening in the classroom." It, thus, appears that the subject panel executive committee had the mandate to select facilitators for the sessions. On the same issue of facilitators, Mapakise remarked: "the committee sits down and chooses facilitators. Sometimes we have volunteers to facilitate." The executive committee seemed to do most of the selection, although some teachers volunteered to facilitate. Chingeve supported what Mberi had said: "Teachers can be selected to facilitate based on the results they produce. The examination results can be a reflection of the competence of the teacher."

Chambara and Zhou also confirmed that examiners were often preferred as facilitators in the subject panels. Three of the four history subject panel meetings, observed by the first researcher, were led by teachers who were also external examiners. However, one panel meeting was facilitated by an external expert, who is the author of several A-Level history textbooks. The selection of the latter seemed to contradict Mberi, who said that they do not hire external experts because they are out of touch with classroom reality, even though it was probably a strategic choice to get insights from the author of the very textbooks that the teachers used for teaching. In summary, it would appear that facilitators for history subject panel meetings are often selected by the executive committee, with occasional input from the teachers.

\section{Agendas for Panel Meetings}

The research solicited participants' views on how agendas for the history subject panel were set. Mberi pointed out that: "We prefer the chairman and his committee to do so. It's mostly the executive committee's duty to set the agenda." Mapakise confirmed thus "the executive... they normally do not consult. They just impose." The executive committee appeared to have the mandate to set the agenda. However, Nyota, Zhou and Zvaita seemed to see things differently. Nyota pointed out that, "At the end of the meeting, there can be a plenary session whereby people are asked to brainstorm issues that proved to be a challenge during the meeting. These are the issues which are tabled for future meetings." Zhou added: "It is the teachers who tell the executive committee what to include in the next meeting." Zvaita expressed similar views when he said that "during meetings, teachers may point out areas in need of further discussions. These form part of the agenda for the next meeting." These three participants seem to suggest that the teachers' input on the agenda was perhaps much more than just occasional.

In further unpacking the issue of teachers'input on the agenda of subject panels, Chambara explained how the teachers' inputs sometimes clashed with the interests of the executive committee: "The executive will be saying, 'last time we discussed syllabus interpretation, so this time we are moving on to examination techniques', but teachers may have unanswered questions on syllabus interpretation. The executive may want progress and move on to new issues." This is when the interests of the executive committee might be seen to override those of the ordinary members of the subject panel. This is perhaps a matter of degree rather than lack of participation in agenda setting altogether.

\section{Activities during Panel Meetings}

Results suggest that three key activities dominated the work of the history subject panel, namely: the involvement of A-level history students in the seminars, improving teachers' educational practice and inducting new history teachers into the profession. 
Godwin MUMHURE, Loyiso C. JITA, Godsend T. CHIMBI. Subject panels as sustainable innovation for teacher professional development

\section{Student Involvement in Seminars}

In a rather uncommon but exciting twist, the history subject panel sessions brought together history teachers and A-level history students. In the interview, Mberi explained that:

Before the seminar begins, some teachers will be marking the tasks given to students for seminar paper presentations. Some will be trying to interpret the questions to the other teachers so that there will be no confusion in front of the students. We will be teaching each other how to mark those essays and making some additions to what students would have written in their essays before students start their presentations.

Document analysis of the minutes of the history subject panel meetings revealed that teachers engaged in syllabus interpretation and the assessment of A-level students' essaywriting skills. In three subject panel meetings, teachers were observed helping each other to interpret and answer A-level history examination questions. Teachers who were external examiners led the discussions, while the other panel members made contributions and raised issues that needed clarification. Chambara pointed out that, "what happens is that schools are given different questions to present and the presentation should be done by students and not teachers. So, we will be having teachers at these seminars, with students presenting. " Similarly, Zhou added that "students do the presentations and those teachers who are examiners will help where pupils fail to present good answers." The themes on the facilitation by teachers who are examiners and student involvement in the activities of the history subject panels recurred in conversations with all the research participants.

\section{Improving Educational Practice}

Mapakise continued to unpack the activities that teachers engaged in during subject panel sessions as follows: "We will be mainly focusing on the best ways that can be adopted to teach the history subject ... This will help teachers to guide students on how they can write better essays at A-level. The main target is to improve the pass rate." He elaborated further: "We mainly focus on technicalities to answer questions, the interpretation part of the questions. The content part-there is a general assumption that every practising teacher has the content of the subject. So, the issue of content is given very little attention." Observations made by the first researcher during a history subject panel meeting held on 8 March 2016 seemed to support what Mapakise described in the interview. During the meeting, teachers mainly asked questions centred on the interpretation of task words in an essay, such as "To what extent", "How far", "Evaluate", and "Discuss". Content was only used to illustrate what the task words meant.

Part of the reason for not focusing on content could be that all A-level history teachers have a minimum of a first degree with history as a major, so it was generally assumed that they have adequate content knowledge of the subject. Chingeve also explained that: "teachers actually look at the questions they find difficult in their respective schools. They bring these to the panel sessions and the executive committee finds teachers who are experts in those areas, and these facilitate the discussions." The focus on improving teachers' pedagogical knowledge during history subject panel sessions appeared to be another recurring theme in the discussions with the participants. 
Godwin MUMHURE, Loyiso C. JITA, Godsend T. CHIMBI. Subject panels as sustainable innovation for teacher professional development

PROBLEMS

OF EDUCATION

IN THE $21^{\text {st }}$ CENTURY

Vol. 78 , No. 5, 2020

808

\section{Inducting New A-level History Teachers}

One critical activity that is somewhat unusual, in which the Masvingo District history subject panel was involved, was the induction of new A-level history teachers into the profession. As Chambara explained:

When you come from university or college, you will be an academic ... but when you are taught in the subject panel, you become a professional. You meet teachers with different experiences, years of teaching in the field and you get information through interaction. They will be teaching you how you teach these students. What you have to focus on is different from the experience that you got from university or college.

New history teachers are inducted into the history classroom by the history subject panel. They collaborated with more experienced colleagues to ease their adaptation into the classroom. Chambara stressed the disparity that often exists between what teachers learn at universities and classroom realities. What teachers learn at universities may be different from what they experience in schools. History subject panels thus seem to be closing the gap between university knowledge and classroom practice, something that is of critical importance, but often neglected in many developing countries with relatively weaker systems of teacher induction. Chingeve also pointed out that, "The moment you are to teach A-Level for the first time, you find out you actually face a lot of complications. It's like you are actually walking on a mine-infested field and you definitely need someone to take you along." In this case, the History subject panel seminars appear to fill an important void on induction by providing new A-level teachers with the much-needed space to solicit and receive help from more experienced colleagues.

\section{Efficacy of the History Subject Panel}

While the history subject panel engaged in a variety of activities to promote teacher professional development, there were militating factors that conspired to undermine the efficacy of the Masvingo District history subject panel. The FGD held with the eight teachers brought out three key threats to the efficacy of the history subject panel. These threats were: poor funding, school principals' negative attitudes and overcrowding at the history seminars.

\section{Poor Funding}

During the focus group interview, the first researcher inquired about the challenges the Masvingo District history subject panel faced. The following are excerpts from the FGD.

Mapakise: The main problem clusters complain about is the issue of funding. Funding is not there, and the members will be struggling to attend the cluster meetings...The schools don't want to give out money. Sometimes, we have to pump out from our pockets.

Chingeve: You will actually find that funding is a problem. Take, for example, when you need funds for typing the much-needed literature for use by teachers, you actually find that the funds are not forthcoming.

Charamba: The school head will say, "your things are expensive to the school. We want to save funds for the school." So, sometimes they won't allow you to go out there because they will say, "you claim travelling and subsistence allowance to go there," and also, "to those seminars you want to claim and to go with those pupils." This is another challenge to the school to fund those pupils to attend these seminars; especially our rural day secondary schools - their funds are limited because parents are poor. 
Godwin MUMHURE, Loyiso C. JITA, Godsend T. CHIMBI. Subject panels as sustainable innovation for teacher professional development

These utterances by the participants paint a rather gloomy picture of the future of the IN THE $21^{\text {st }}$ CENTURY Vol. 78, No. 5, 2020 subject panels. School principals, who are expected to support teacher professional development, often seem to be constrained or perhaps even unwilling to fund subject clusters. The challenge of inadequate financial resourcing of most rural (and sometimes urban) schools could militate against formation and sustainability of effective subject panels. But referring to history subject cluster activities as "your things" may also suggest that the principal (at Chambara's school) did not have a favourable attitude towards the history subject panel.

\section{School Principals'Negative Attitudes}

The FGD also brought out the issue of some school principals' negative attitudes towards the history subject panel.

Zhou: There are some teachers who complain about administration in their schools. There are some who say that their headmasters refuse to give them permission to attend these panel meetings. And in some cases, they in fact complain about financial issues. When you attend such a committee [subject panel meeting], you are supposed to be financed by the school, then some headmasters say the school does not have money and attendance is not always $100 \%$ because of headmasters' lack of support.

Nyota: The schools don't want to give out money... when we attended a certain panel meeting at Ndarama, we had to go there using our own means, out of our own interest. We had to pump out from our own pockets.

Mapakise: The National Association of Secondary School Heads (NASH) often pledges to sponsor, but sometimes you will find NASH hasn't given us anything. They just say write down your names and the number of people attending and take the minutes.

Some school heads' negative attitudes towards subject panels made teachers and students use their own resources to attend history subject panel activities. Some of the principals complained that the subject panels were a waste of scarce financial resources. Others saw the panels as creating two centres of power because they were not under their administrative control because they were led by teacher leaders. The issue of school heads denying teachers the opportunity to participate in history subject panels surfaced several times during the oneon-one interviews as well as the FGD.

\section{Overcrowding at Seminars}

One issue which spontaneously emerged during the FGD was that of overcrowding during the subject panel seminars that involved A-level history students. The issue of space was not captured in the focus group interview guide because the researchers had never thought of it when they constructed the guide. Chingeve brought up the issue of space as a challenge to the efficacy of their history subject panel.

Chingeve: There is overcrowding at seminars and some teachers come late for meetings due to transport problems.

Mberi: At times, there is overcrowding at these panels and sharing of information becomes a problem.

Nyati: Too many students are difficult to control, and this makes the panel seminars ineffective.

Nyota: Overcrowding at seminars leads to poor communication, causing student disciplinary problems.

Zhou: But gentlemen the problem of overcrowding is not for our seminars only. All schools in our country are overloaded. We have classes with more than 50 students each.

Mberi: Overcrowding at our seminars is a problem we have to learn to live with. This is a policy issue which we may never be able to solve. Like Mr Zhou is pointing out even classes at our schools are overloaded. 
Godwin MUMHURE, Loyiso C. JITA, Godsend T. CHIMBI. Subject panels as sustainable innovation for teacher professional development

PROBLEMS

OF EDUCATION IN THE $21^{\text {st }}$ CENTURY Vol. 78, No. 5, 2020

810

Overcrowding at seminars was a theme that emerged during the FGD with participants which the researchers had not anticipated when they prepared the focus group interview guide. The first researcher later observed the problem of lack of space at the venue where a seminar was held with A-level history students. He observed that it was difficult for the facilitators to respond to all the concerns raised by students due to overcrowding. Many A-level history students appeared eager to attend the subject panel seminars and participate in the learning communities created.

\section{Discussion}

This research explored and unpacked the activities and efficacy of one history subject panel as an innovative grassroots model for teacher professional development. García-Martínez and Tadeu (2018) observed the shortcomings of preservice training for secondary school teachers when they pointed out that, "the professionals who practice in secondary school lack specific training as teachers. Because for decades, training has been committed to the mastery of content rather than the possession of pedagogical skills, these teachers have gaps that limit their teaching practices" (p. 149). The current research on the history subject panel as an innovation for teacher professional development can be an important bridge to the gap between what new teachers learnt in universities and what they experience in the classroom. Results from the current research indicate that, given the opportunity, subject panels can play a key role in the staff development of novice colleagues, who can benefit from interaction with experienced colleagues. This shows that the proverbial "Doctor, heal thyself" is indeed possible if teachers are afforded the opportunity to staff develop each other; instead of waiting for external experts (who are far detached from everyday classroom practice) to come and tell them what to do to improve their practice and learner performance.

Some key findings from this research seem to speak directly to existing literature. For instance, the history subject panel executive committee selected knowledgeable and experienced panel members to be facilitators for the seminars, instead of hiring external experts. This aligned with research by Stacy (2013), which established that professional development for teachers should utilise local expertise so that, "teachers can reclaim their professional autonomy by becoming experts within their schools" (p. 46). The use of local experts also supports RinconGallardo and Fullan's (2016) assertion that empowered teachers can help improve colleagues' instructional practice.

However, some results from the current research seem to contradict the principles of democratisation embedded in existing literature. Tikkanen et al. (2019) suggested that facilitators for teacher professional development sessions should be chosen by the teachers themselves to increase collegiality. While in some cases, the teachers self-selected themselves to facilitate the history panel sessions, there were instances where the executive could be seen to impose with relatively little input from the teachers. A balancing act is often needed in the development of the agenda, to encourage ownership and engagement by the teachers. Hargreaves et al. (2013) argued in favour of teacher involvement in planning professional development programmes so that teachers' needs are reflected. Mansfield and Thompson (2016) argued for teacher involvement in agenda-setting to increase ownership and commitment to professional development initiatives.

The use of the history panel to induct new A-level history teachers into the teaching profession and the creation of student learning communities appeared to be two novel practices emanating from the current study, hitherto undocumented in existing literature. While existing literature suggested that subject panels play an important role in teacher professional development, the unique findings in the current research add new dimensions to the role of subject panels. The history subject panel case studied appeared to be taking a new professional 
role of inducting new history teachers into the profession and creating learning communities communities or communities of practice for teachers, and not for students (Chikoko, 2007; Jita \& Mokhele, 2012; Shikalepo, 2018; Tikkanen et al., 2019). The Masvingo District history subject panel seemed to be adding a new dimension to the concept of learning communities by bringing together A-level history students so that they could learn from one another, instead of relying on their subject teachers. Student learning communities can be extended to all the subjects offered in the school curricula; and can be internationalised as an innovation to improve learner performance across the globe.

\section{Conclusions and Implications}

This research examined the activities and efficacy of one history subject panel as an innovation for teacher professional development in Masvingo Province in Zimbabwe. The case study of a history subject panel generated new insights into how subject panels can be used to induct new teachers into the profession and organise history students into learning communities, not only in Zimbabwe, but throughout the world.

The innovation on teacher induction using subject panels, if sustained and extended to all the subjects offered in the school curricula, can bridge the gap between theory taught in schools of teacher education in universities and practice existing in schools. Sustainability and going-to-scale will, however, not be possible without due collaboration with policymakers, school principals and learners. The missing voices of the policymakers, principals and students in the current research are gaps that can be pursued in future studies on subject panels and their efficacy in different contexts and countries. The formation and sustainability of student learning communities is yet to be studied further and documented in depth, pointing new directions for future research. Although students are the chief client in all education systems, and the ultimate beneficiaries from teacher professional development, they are often marginalised in research on how classroom practice can be improved. Future research on learning communities for teachers can be reconceptualised to include policy makers, school principals and students in different countries.

In its own contribution, this research dispels the myth that teachers cannot come up with sustainable solutions to challenges they encounter in their practice. Indeed, under the right conditions, it is possible for subject panels to provide useful innovations to teacher professional development in different countries, reducing dependency on external experts who may be far removed from classroom situations and the problems teachers encounter in their daily practice. Who else can be better placed to seek solutions to challenges in classroom practice and learner performance than the teachers themselves?

\section{Acknowledgements}

This paper is generated from an unpublished PhD thesis: Mumhure, G. (2017). Zimbabwean teachers' perspectives on the history subject panels as an innovation for professional development. Unpublished doctoral thesis. Bloemfontein, South Africa: University of the Free State.

\section{References}

Ajani, O. A. (2019). Effective teachers' cluster system as an approach to enhanced classroom practices in South African High Schools. Journal of Gender, Information and Development in Africa, 8(1), 173-194. https://doi.org/10.31920/2050-4284/2019/8n1a8 
Godwin MUMHURE, Loyiso C. JITA, Godsend T. CHIMBI. Subject panels as sustainable innovation for teacher professional development

PROBLEMS

OF EDUCATION IN THE $21^{\text {st }}$ CENTURY Vol. 78, No. 5, 2020

812

Ajani, O. A., \& Govender, S. (2018). Using cluster system as an effective teachers' professional development for improved instructional development. Gender and Behaviour, 16(3), 1196311969.

Battersby, S. L., \& Verdi, B. (2015). The culture of professional learning communities to improve teacher efficacy and support student learning. Arts Education Policy Review, 116(1), 2229.

Bett, H.K. (2016). The cascade model of teachers' CPD in Kenya: A time for change? Cogent Education, 3(1), 1-9. https://doi.org/10.1080/2331186X.2016.1139439

Bogdan, R. C., \& Biklen, S. K. (2003). Qualitative Research for Education: An Introduction to Theories and Methods (4th ed.). Allyn and Bacon.

Chikoko, V. (2007). The school cluster system as an innovation: Perspectives of Zimbabwean teachers and school heads. Africa Education Review, 4(1), 42-57.

Chikoko, V., \& Aipinge, L. (2009). The school cluster system as an educational reform: Evidence from Namibia and Zimbabwe. Southern African Review of Education, 15(1), 25-43.

Cohen, L., Manion, L., \& Morrison, K. (2011). Research methods in education. Routledge.

Creswell, J.W. (2013). Qualitative inquiry and research design: Choosing among five approaches. Sage.

Day, C., \& Sachs, J. (2004). International handbook on the CPD of teachers. Open University Press.

Dehghan, F. (2020). Teachers' perspectives of professionalism: A top-down or bottomup decision-making process? Professional Development in Education, 46(1), 1-10. https://doi.org/10.1080/19415257.2020.1725597

Delport, A., \& Makaye, J. (2009). Clustering schools to improve teacher professional development: Lessons learnt from a Zimbabwean case study. Africa Education Review, 6(1), 96105.

Falyakhov, I. (2018). Corporate qualifications of the mentor in the dual education system. Journal of Social Studies Education Research, 9(2), 89-103.

García-Martínez, I., \& Tadeu, P. (2018). The influence of pedagogical leadership on the construction of professional identity: A systematic review. Journal of Social Studies Education Research, 9(3), 145-162.

Gore, J., \& Rosser, B. (2020). Beyond content-focused professional development: Powerful professional learning through genuine learning communities across grades and subjects. Professional Development in Education, 46(1), 1-16. https://doi.org/10.1080/19415257.2020.1725904

Govender, S. (2018). South African teachers' perspectives on support received in implementing curriculum changes. South African Journal of Education, 38(2), S1-S12.

Haralambos, M., Holborn, M., Chapman, S., \& Moore, S. (2013). Sociology: Themes and Perspectives. Harper-Collins Publishers.

Hardman, F., Hardman, J., Dachi, H., Eliott, L., Ihebuzor, N., Ntekim, M. \& Tibuhinda, A. (2015). Implementing school-based teacher development in Tanzania. Professional Development in Education, 41(4), 602-623. https://doi.org/10.1080/19415257.2015.1026453

Hargreaves, E., Berry, R., Lai, Y.C., Leung, P., Scott, D., \& Stobart, G. (2013). Teachers' experiences of autonomy in continuing professional development: Teacher learning communities in London and Hong Kong. Teacher Development, 17(1), 19-34. https://doi.org/10.30918/AERJ.62.18.008

Jita, L. C., \& Mokhele, M. L. (2012). Institutionalising teacher clusters in South Africa: Dilemmas and contradictions. Perspectives in Education, 30(2), 1-11.

Kennedy, A. (2011). Collaborative continuing professional development (CPD) for teachers in Scotland: Aspirations, opportunities and barriers. European Journal of Teacher Education, 34(1), 25-41.

Mansfield, C., \& Thompson, G. (2016). The value of collaborative rounds for teacher professional learning in Australia. Professional Development in Education, 43(4), 666-684. http.//eprints.qut. edu.au/94074/

Maphahlele, L. K., \& Rampa, S. H. (2015). Cluster system: An innovative network for teacher development. Procedia: Social and Behavioural Sciences, 116, 3131-3134.

Maphosa, C., Mutekwe, E., Machingambi, S., Wadesango, N., \& Ndofirepi, A. (2013). School clusters in Zimbabwe: What issues do clusters tackle? International Journal of Science, 5(3), 293-300.

Mokhele, M. L. (2011). Teachers' perspectives on continuing professional development: A case study of the Mpumalanga Secondary Science Initiative (MSSI) project. Unpublished doctoral thesis. Pretoria, South Africa: University of South Africa.

Nakambonde-Daniel, J. (2018). The role of school cluster system as a support service for teachers: A case of Oluno Circuit in the Oshana Region of Namibia. Unpublished master's dissertation. Windhoek, Namibia: University of Namibia. 
Godwin MUMHURE, Loyiso C. JITA, Godsend T. CHIMBI. Subject panels as sustainable innovation for teacher professional development

Ngcoza, K., \& Southwood, S. (2015). Professional development networks: From transmission to construction. Perspectives in Education, 33(1), 1-11.

Ngema, M., \& Lekhetho, M. (2019). Principals' role in managing teacher professional development through a training needs analysis. Problems of Education in the $21^{\text {st }}$ Century, 77(6), 758-773. https://doi.org/10.33225/pec/19.77.758

Nwagbara, A. C. (2014). The effectiveness of teachers and school cluster model of primary school mathematics teachers' professional development in Cross River State, Nigeria. Asia Pacific Journal of Education, Arts and Sciences, 1(3), 12-19.

Owens, M. A., Pogodzinsk, B., \& Hill, W. E. (2016). Job-embedded professional development policy in Michigan: Can it be successful? Professional Development in Education, 42(2), 201-217.

Picower, B. (2015). Nothing about us without us: Teacher driven critical professional development. Radical Pedagogy, 12(1), 1-26.

Rabbie, F. (2004). Focus-group interview and data analysis. Proceedings of the Nutrition Society, 63, 655-660. https://doi.org/10.1079/PNS2004399

Rincon-Gallardo, S., \& Fullan, M. (2016). Essential features of effective networks in education. Journal of Professional Capital and Community, 1(1), 5-22.

Shikalepo, E.E. (2018). School cluster system for quality education in rural Namibian schools. African Educational Research Journal, 6(2), 48-57.

Spillane, J. (2000). A fifth-grade teacher's reconstruction of mathematics and literacy teaching: Exploring interactions among identity, learning and subject matter. The Elementary School Journal, 100(4), 307-330. http,//www.jstor.org/stable/1002135

Stacy, M. (2013). Teacher-led professional development: Empowering teachers as self-advocates. The Georgia Social Studies Journal, 3(1), 40-49.

Starkey, L., Stevens, S., Taylor, M., Tolia, R., Yates, A., Hall, C., McKenzie, L., \& Meyer, L. (2007). School/cluster-based secondary qualifications professional development. Ministry of Education Research Division.

Tikkanen, L., Pyhalto, K., Pietarinen, J., \& Soini, T. (2019). Lessons learnt from large-scale curriculum reform: The strategies to enhance development work and reduce reform-related stress. Journal of Educational Change, 1-25. https://doi.org/10.1007/s10833-019-09363-1

Villegas-Reimers, E. (2003). Teacher professional development: An international review of the literature. UNESCO.

Wong, J., \& Bautista, A. (2017). How do teachers define the notion of professional development? The case of primary music teachers. Professional Development in Education, 44(4), 539556. https://doi.org/10.1080/19415257.2017.1369450

Yates, A. (2012). Devolving professional learning to subject specialists: Towards embedding assessment reform in New Zealand. Professional Development in Education, 38(4), 613629. https://doi.org/10.1080/19415257.2011.635308 
Godwin MUMHURE, Loyiso C. JITA, Godsend T. CHIMBI. Subject panels as sustainable innovation for teacher professional development

PROBLEMS

OF EDUCATION

IN THE $21^{\text {st }}$ CENTURY

Vol. 78, No. 5, 2020

814

Cite as: Mumhure, G., Jita, L. C., \& Chimbi, G. T. (2020). Subject panels as sustainable innovation for teacher professional development. Problems of Education in the $21^{\text {st }}$ Century, 78(5), 799-814. https://doi.org/10.33225/pec/20.78.799

Godwin Mumhure

PhD in Curriculum Studies, Principal of Morgenster Teachers College, P.O. Box Morgenster, Masvingo, Zimbabwe.

E-mail: mumhuregodwin@yahoo.com

Loyiso C. Jita

$\mathrm{PhD}$, Professor, Dean and SANRAL Chair in Mathematics and Sciences,

Faculty of Education, University of the Free State, P. O. Box 339, Bloemfontein

9300, Republic of South Africa.

E-mail: jitalc@ufs.ac.za

ORCID: https,//orcid.org/0000-0001-6871-6820

Godsend T. Chimbi

(Corresponding author)
PhD in Curriculum Studies, Post-Doctoral Research Fellow under the SANRAL Chair in the Faculty of Education, University of the Free State, P. O. Box 339,

Bloemfontein 9300, Republic of South Africa.

E-mail: ChimbiGT@ufs.ac.za

ORCID: https,//orcid.org/0000-0002-6417-4355 